Pasado y Memoria

ISSN: 2386-4745

Núm. 23, 2021, pp. 160-183

https://doi.org/10.14198/PASADO2021.23.07

Dossier monográfico

\title{
La teoría y la práctica de la contrarrevolución en el monarquismo autoritario durante la Segunda República española
}

\author{
Counterrevolution Theory and Practice in \\ Authoritarian Monarchism during the Second Spanish \\ Republic
}

\author{
Eduardo González Calleja \\ Universidad Carlos III de Madrid, España \\ edgcalle@hum.uc3m.es \\ https://orcid.org/0000-0003-1184-4383
}

Recibido: 13/02/2021

Aceptado: 29/04/2021

Cómo citar este artículo: GONZÁLEZ CALLEJA, Eduardo (2021). La teoría y la práctica de la contrarrevolución en el monaquismo autoritario durante la Segunda República española. Pasado y Memoria. Revista de Historia Contemporánea, (23), pp. 160-183, https:// doi.org/10.14198/PASADO2021.23.07

\section{Resumen}

El presente trabajo analiza las justificaciones de la violencia elaboradas durante la Segunda República desde los diversos sectores del monarquismo alfonsino, la tendencia de extrema derecha que animó con mayor insistencia una reflexión teórica sobre la contrarrevolución, y los medios para impulsarla por vías de hecho. Todo ello dio lugar a una auténtica utopía insurreccional que fue apoyada por los sectores más extremistas de la Iglesia y el Ejército. Tomando como ejemplo las reflexiones de Ramiro de Maeztu y José Calvo Sotelo sobre el militarismo, se analiza la construcción retórica de una acción subversiva para la que, en principio, no existían condiciones inmediatas de realización, pero cuya minuciosa y tenaz formulación abrieron un espacio de oportunidad política que acabó por materializarse en el golpe de Estado militar de julio de 1936. 
Palabras clave: Contrarrevolución; España; Golpe de Estado; José Calvo Sotelo; Militarismo; Ramiro de Maeztu; Segunda República española.

\begin{abstract}
This paper studies the justifications of violence provided during the Second Republic by the various sectors of pro-Alphonse monarchism -the far-right wing, which encouraged with greater insistence a theoretical reflection on the counterrevolution and the means to promote it in fact. All that arose a genuine insurrectional utopia which was supported by the radical sectors of the Church and the Army. Taking as an example the reflections on militarism of Ramiro de Maeztu and José Calvo Sotelo, we analyze the rhetorical construction of subversive action which, in principle, was not likely to be immediate, but whose thorough and tenacious formulation opened the way to a space of political opportunity that finally materialized in the July 1936 military coup d'État.
\end{abstract}

Key words: Counterrevolution, Spain; Coup d'État; José Calvo Sotelo; Militarism; Ramiro de Maeztu; Second Spanish Republic.

Durante la Segunda República, algunos de los más destacados grupos de la derecha española especularon sobre los medios de frenar por vías de hecho lo que consideraban una revolución en marcha, alumbrando una auténtica utopía insurreccional según el término acuñado por Irene Castells (1988: 440) para definir los levantamientos liberales de la Década Ominosa. El texto se centrará en analizar las justificaciones teóricas de la contrarrevolución elaboradas desde los sectores más claramente involucionistas de las derechas españolas, en especial los monárquicos alfonsinos, que elaboraron el corpus doctrinal más coherente, apoyados por los sectores más irreductibles de la Iglesia y el Ejército.

\title{
1. La crítica al accidentalismo y la justificación del golpe de Estado en la publicística monárquica de la primera hora
}

Para los tradicionalistas, las posibilidades de encontrar puntos de acuerdo con una República sumida en todos los males de la modernidad (pluralismo ideológico, igualdad civil, laicismo, autodeterminación individual y colectiva, etc.) eran, desde el primer momento, nulas. Lo mismo se podía decir de la extrema derecha alfonsina, que fue adoptando un nacionalismo integral de influencia maurrasiana repleto de constantes apelaciones a la subversión militar.

No resultó extraño que una de las primeras utilizaciones políticas del derecho público cristiano contra la República procediera del campo tradicionalista. En una conferencia pronunciada en Valencia el 3 de abril de 1932, Manuel Senante, director de El Siglo Futuro, trató de esbozar toda una doctrina 
respecto de la licitud de la resistencia a los poderes ilegítimos y de hecho, analizando de forma paralela el ralliement de la Iglesia francesa a la Tercera República y la actitud de los católicos españoles frente al régimen a un año de su proclamación. Para el pensamiento integrista, toda autoridad procedía de Dios, aunque el derecho a ejercerla lo otorgase la nación, ya fuera por elección directa (república o monarquía electiva), ya fuera por elección trascendente (monarquía hereditaria). Sin embargo, el poder podía ser ilegítimo de origen o ejercicio, con lo cual el pueblo no estaba obligado a obedecer, e incluso podía actuar en su contra, descalificando la doctrina tomista de acatamiento del poder y de condena de toda acción violenta contra una autoridad ya establecida. Esta teoría, según Senante, no era válida si lo que se buscaba era «reconquistar» la soberanía perdida por una usurpación (el caso de la lucha de legitimidades entre carlistas y alfonsinos, y de ambos contra una República instaurada por vía revolucionaria), y sobre todo si el poder de hecho se encontraba amenazado por una revolución según el viejo silogismo donosiano de que el liberalismo albergaba en su seno la república, y que ésta degeneraría irremisiblemente en socialismo, comunismo y anarquía. Para fundamentar su aserto, Senante desempolvó la encíclica Cum Multa dirigida en 1882 por León XIII a los católicos españoles para que salvaran los intereses de la religión sin adherirse necesariamente a la monarquía alfonsina, con lo cual, y forzando el razonamiento, la doctrina papal no obligaba a ningún reconocimiento posterior de poderes, y mucho menos el de una república (Senante, 1932: 40-44 y 73-77).

Desde la órbita del alfonsismo más extremista también se atacó con dureza la doctrina del ralliement, considerada como el preludio de las medidas de "persecución religiosa» de 1902-1905. En su obra Catolicismo y república (1934), esbozada como conferencia el 23 de febrero de 1932 en la Sociedad Cultural Acción Española, Eugenio Vegas Latapié se sirvió de la crítica maurrasiana al acercamiento del catolicismo francés a la Tercera República para atacar duramente las tesis accidentalistas defendidas por el cardenal Francisco Vidal y Barraquer y el nuncio Federico Tedeschini, ya que, en su opinión, no calibraban el carácter francamente revolucionario y subversivo de las instituciones republicanas. Las lucubraciones sobre la ilegitimidad de ejercicio de los gobiernos republicanos por su impulso a una «legislación sectaria» que era incompatible con los principios católicos darían mucho juego en el futuro más inmediato.

Tras el fracaso del pronunciamiento encabezado por el general Sanjurjo en agosto de 1932, los católicos más intransigentes comenzaron a plantearse en serio la posibilidad de difundir un riguroso corpus doctrinal para el siguiente asalto contra el régimen, que al ser considerado injusto y tiránico justificaba el impulso de un movimiento de rebeldía cristiano y patriótico. La Ley de 
Confesiones y Congregaciones Religiosas, votada el 17 de mayo de 1933 y aprobada el 2 de junio, provocó un empeoramiento de las relaciones entre la Iglesia y el Estado. La pastoral colectiva de los obispos solicitando la resistencia pasiva, que fue hecha pública el mismo día de la votación parlamentaria, fue apoyada al día siguiente por el Papa a través de la encíclica Dilectissima Nobis, una vez que la Ley del Tribunal de Garantías Constitucionales hurtara la revisión inmediata de las leyes complementarias de la Constitución aprobadas en las Cortes. Este decantamiento hacia la confrontación aceleró la organización de una derecha accidentalista (la CEDA) que surgió en marzo de 1933 bajo el amparo de la jerarquía eclesiástica para defender la "civilización cristiana», combatir la legislación «sectaria» y revisar la Constitución en sentido corporativo y autoritario. Pero también animó de forma definitiva a muchos canonistas y teólogos a reelaborar y glosar los principios católicos de resistencia al poder ilegítimo.

Un fruto indirecto y peculiar esta doctrina de resistencia a la tiranía fue el conjunto de conferencias pronunciadas en abril de 1933 en el seno de la Juventud Monárquica de Bilbao y publicados con el sugestivo título -inspirado sin duda en los escritos de Maurras, cuya influyente obra Encuesta sobre la Monarquía aparecería publicada en castellano en 1935- de Aspectos del golpe de Estado. En estas conferencias, Joaquín de Zayas expuso la doctrina católica al respecto, aseverando que la resistencia armada era lícita cuando la tiranía era manifiesta, no había otra posibilidad de oposición, la acción tenía posibilidades de éxito y la caída del tirano no conllevaba un mal mayor. En su opinión, todos estos casos, en especial el último, se daban en España, y la Iglesia no debía oponerse a un golpe reaccionario encaminado a la conquista de un poder que hasta entonces había sido utilizado para destruir la fe cristiana. La futura alcaldesa franquista de Bilbao, María del Pilar Careaga, se ocupó de las circunstancias, requisitos y condiciones para hacer viable el golpe de Estado, armonizando la concepción católica de la resistencia política con las teorías maurrasianas del coup d'état (Maurras; Dutrait-Crozon, 1910) El principal requisito para su aplicación era el empleo de la fuerza como complemento del derecho y el orden. La fuerza debía ser apoyada y fijada por una idea (la Monarquía) cuando el derecho fracasaba ante la ilegitimidad del régimen que debía sancionar. Entre las varias causas desencadenantes un golpe de fuerza enumeraba factores extrínsecos (malestar, hastío, anarquía, una derrota militar, desprestigio del poder) e intrínsecos (propaganda, organización), además de la existencia de una doctrina contrarrevolucionaria clara, concisa, con un programa preciso, flexible y factible; con un líder político como Cánovas que reuniera los poderes necesarios para la organización del golpe, su ejecución, consolidación y ulterior obra de gobierno, y con un príncipe que tuviera arraigo en la voluntad y en 
la tradición nacionales, que no fuera extranjero ni llegara al trono traído por artificios electorales o plebiscitarios. Evidentemente, el ambiente de subversión intelectual afectaba de forma notoria a los círculos monárquicos en todas sus manifestaciones. Incluso Eugenio Vegas Latapié prologó en la primavera de 1936 la novela de ambiente cristero mexicano Héctor o los mártires del siglo $X X$ de Jorge Gram, en donde se preconizaba el alzamiento en armas contra los enemigos de Dios y de la patria. El texto apareció en el diario monárquico La Época, pero Vegas, temeroso de una sanción en virtud de su grado militar, negó la autoría (Vegas Latapié, 1940: 14-15).

\section{Acción Española y la difusión de la doctrina del «derecho a la rebeldía»}

La revista doctrinal y la sociedad cultural Acción Española fueron las herramientas más notorias empleadas por los monárquicos para fundamentar teóricamente los trabajos políticos encaminados a una restauración de contornos claramente contrarrevolucionarios (González Cuevas, 1998). Su actividad estaba inspirada en L'Action Française y el movimiento legitimista galo, uno de los más fuertes y mejor estructurados organizativa e ideológicamente de Europa. El mismo nombre de la revista era un ejemplo de esta identidad de estrategias, coincidentes con las consideraciones realizadas por Vegas Latapié respecto a anteriores tentativas antirrevolucionarias frustradas. No se trataba de restaurar la Monarquía liberal, sino de instaurar una Monarquía «nueva», de contornos neotradicionalistas. Mientras que colaboradores como Pedro Sáinz Rodríguez desconfiaban de la eficacia de impulsar una estrategia «pedagógica» sobre las minorías dirigentes del país, y postulaban un golpe militar fulminante, Vegas opinaba que pretender impulsar un cambio por medio de un golpe de fuerza o de un proceso electoral era utópico antes de que los hombres se hubiesen convencido de la necesidad de esta acción:

«La única salida a la democracia es que las clases directoras estén en posesión de otra doctrina fundada en la verdad política. Primo de Rivera y otros dictadores de Iberoamérica, salvo el Portugal integralista, fracasaron por falta de una doctrina contrarrevolucionaria firme. La acción debe ser el complemento de dicha doctrina ('la fe sin obras es fe muerta'). En tiempo de Nehemías, los hombres del pueblo escogido con una mano manejaban el martillo, construyendo el Templo de Jerusalén, y con la otra empuñaban la espada para defenderse de los ataques de los enemigos [... ¡A Acción! ¡Hay que actuar! Ante los males de la religión y de la patria a nadie es lícito permanecer ocioso [...] Combatiremos el mal con una mano y con la otra edificaremos el Estado nuevo» ${ }^{1}$.

1. «Doctrina y Acción», editorial de Acción Española [en adelante, AE], n. ${ }^{\circ} 29,16-\mathrm{V}-1933$, p. 449, cit. en Vegas Latapié, 1940: 46-47. 
Esta cita bíblica -una sua manu faciebat opus et altera tenebat gladium(Nehemías, 4, 11), aparecida en el epílogo de la Historia de los heterodoxos de Marcelino Menéndez Pelayo, se convertiría en el lema de la revista. Maeztu y sus acólitos confiaban en un colapso más o menos próximo del régimen republicano y en la posibilidad de constituirse en la élite orientativa de una eventual dictadura militar previsible o preparada por ellos mismos (González Cuevas, 2003: 277). Se trataba de armonizar la inteligencia con la fuerza militar, tras años de pretorianismo primorriverista: «Habíamos cultivado las espadas, y por eso el día de la crisis de las espadas se encontraron con que no sabían a dónde dirigirse. Habíamos olvidado el alma que había de dirigir las espadas. Por eso fundamos Acción Española $»^{2}$. Un editorial de Acción Española recalcó suficientemente esta convicción: «Sólo se vence la revolución derrotando previamente la ideología revolucionaria $»^{3}$.

Raúl Morodo (1980: 57) afirmó que Acción Española estaba dentro del esquema conspirativo monárquico y hacía justicia a su lema de contraportada. Los intelectuales de esta tendencia sacaron conclusiones de los efectos perversos que podía tener una intervención militar continuada en la política, de modo que postularon la intervención del Ejército sólo en situaciones extremadamente graves, tales como la amenaza a la unidad de la patria, la destrucción, el desmoronamiento o la desvirtuación de las Fuerzas Armadas, el atentado a la disciplina y la amenaza al orden social y público (Sáinz Rodríguez, 1980: 242). Dichas condiciones prerrevolucionarias parecían darse con la República, y los monárquicos se lanzaron muy tempranamente a organizar un golpe de Estado como paso previo a la restauración (González Calleja, 2011: 28-50). Sin embargo, faltaban una teoría y una táctica que analizaran metódicamente los medios con que la contrarrevolución pudiera imponerse a un ambiente popular hostil. En ese sentido, la aparición de libro de Curzio Malaparte Técnica del golpe de Estado fue acogida con interés en las páginas de la revista:

«El estudio de la técnica seguida por Mussolini para preparar su advenimiento al poder puede servir de ejemplo demostrativo de cómo puede triunfar un golpe de Estado teniendo en contra masas obreras organizadas: basta con desorganizarlas» ${ }^{4}$.

Los neotradicionalistas de Acción Española interpretaron la Segunda República como una fase más de la revolución mundial (en sus sucesivas etapas liberal, democrática y marxista) iniciada en el siglo XIX, y con una facies socialista

2. AE, n. ${ }^{\circ} 46,1-1 \mathrm{II}-1934$, p. 1.021 .

3. AE, n. ${ }^{\circ}$ 62-63, 1-X-1934, pp. 13, cit. por Marrero, 1962: 253.

4. Eugenio Vegas Latapié, «Lecturas: Técnica del golpe de Estado, por Curzio Malaparte», AE, n. ${ }^{\circ}$ 1, 19-XII-1931, pp. 100-101. 
desde 1917, a la que se enfrentaba una contrarrevolución ineficaz hasta la aparición del fascismo (Gil Pecharromán, 1986: 289-294). Uno de los grandes debates que se plantearon en el seno de la publicación fue el del modelo más apropiado de régimen contrarrevolucionario. El recuerdo del triste final de la Dictadura, que fue contemplado como la antesala de la República, justificaba que, en términos generales, las dictaduras fueran consideradas magistraturas excepcionales, y por lo tanto episódicas. Como demostró el régimen primorriverista, el Ejército sufrió un desgaste político, inevitable en todo ejercicio del poder, que le incapacitó para actuar como dique de la ulterior revolución. Acción Española dedujo esta enseñanza de la intervención continuada del Ejército en la política: «las dictaduras son remedios pasajeros que acaban, al poco tiempo, entregando de nuevo el país a sus agentes destructores ${ }^{5}$. Sólo un régimen poseedor de una verdadera doctrina contrarrevolucionaria estaba en condiciones de perdurar y de afrontar las amenazas de la democracia y el comunismo. Siguiendo la tónica marcada por Cánovas durante la Monarquía de Sagunto, Acción Española postuló la intervención política de las Fuerzas Armadas sólo en situaciones consideradas extremadamente graves, pero difería del prócer malagueño al considerar este acto de fuerza como el punto de partida necesario para una auténtica restauración del orden político monárquico en su forma estrictamente tradicional, con el Ejército como principal garante del nuevo régimen (Lleixà, 1984).

Los más conspicuos representantes de Acción Española, como Maeztu, Pradera, Vigón, Vázquez Dodero o Pemán, difundieron la doctrina tomista sobre las condiciones que se debían cumplir para que el pueblo católico pudiera levantarse contra un tirano. Desde las páginas de la revista, clérigos como Pablo León Murciego enunciaban de esta manera el deber de resistencia de los católicos:

«Si el poder público, desatendiendo el bien general, sólo se cuida del provecho propio; si agobia a sus súbditos por todos los medios que les sugieren sus pasiones; si está dominado por el odio a grandes sectores de la nación; si se deja arrastrar de la avaricia y de la ira; si nadie goza de seguridad y todo es incierto, porque no es la justicia la que rige, sino el capricho y la liviandad del que manda; si no sólo oprime a los súbditos en las cosas temporales, sino que las impide su mismo bien espiritual; si menosprecia a Dios y para nada cuida de las leyes morales; si lejos de conducir rectamente a los ciudadanos a su fin, se desvía lastimosamente de él, entonces el poder público se convierte en tiránico, el cual no sólo se puede, sino que se debe derrocar, y, por doble motivo, si a esta ilegitimidad de ejercicio se agrega la de origen por haber nacido el mando

5. Editorial «A los dos años», AE, n. ${ }^{\circ}$ 43, 16-XII-1933, p. 627, cit. por Ansón, 1960: 130. 
de las entrañas impuras de un motín. En este caso la resistencia al Poder no sólo no es sedición ni rebeldía, sino que es un deber ${ }^{6}$.

Bastante antes del inicio de las elecciones de noviembre de 1933, Acción Española inició una campaña para legitimar el derecho a la rebeldía contra el régimen republicano ${ }^{7}$. Ese verano, el integrista santanderino Marcial Solana publicó un compendio de las teorías sobre la resistencia a la tiranía según la doctrina de Tomás de Aquino y los tratadistas del Siglo de Oro español, y en 1934, tras un comentario encomiástico aparecido en El Siglo Futuro el 3 de febrero, dio a la luz un nuevo estudio sobre la aplicación de la teoría de la tiranía a los regímenes democráticos y constitucionales. Señalando directamente a la República española, advertía que el derecho público cristiano no exigía que la autoridad estuviese concentrada en un solo sujeto para ser considerada despótica ${ }^{8}$.

El ensayo más completo en esta línea fue El Derecho a la Rebeldía del jesuita Aniceto de Castro Albarrán (1933 y 1941), considerado «el progenitor doctrinal del levantamiento armado contra la República» (Iturralde, 1955-1965: 440-446). Partiendo de la teoría iusnaturalista de que todo poder, y por tanto toda autoridad, procedía de Dios y debía ir dirigido al bien común, Castro Albarrán intentaba desmontar el mito democrático del sufragio universal que considera que la autoridad procedía de ese acto ciudadano soberano, cuando el pueblo, según la doctrina tomista, no era sino un canal de la divina autoridad. Demostrada la ilegitimidad de la democracia en ese aspecto de iure, además de por el falseamiento de facto del sufragio (una referencia insidiosa a las elecciones del 12 de abril y 28 de junio de 1931), el magistral de Salamanca aseguraba que no existía una forma de gobierno preferible, sino que la más apropiada es aquélla que respetase los principios de la religión y de la moral cristianas, características que, según su opinión, nunca había cumplido la democracia europea, y menos las repúblicas, que eran consideradas enemigas naturales de la Iglesia. Sentadas estas bases mínimas de relativismo político, un régimen sería legítimo si contaba con el consentimiento del pueblo y actuaba para su bien, cosa que la República no hacía, ya que sólo representaba a la coalición de

6. Pablo León Murciego, «El deber de la resistencia. El hecho no crea derecho», $A E, \mathrm{n}^{\circ}{ }^{\mathrm{0}} 43$, 16-VII-1933, pp. 240-241.

7. Carlos Fernández Cuenca, «Lecturas: Regimiento de Príncipes, de Santo Tomás de Aquino», AE, n. ${ }^{\circ}$ 21, 16-I-1933, pp. 329-333.

8. «La resistencia a la tiranía, según la doctrina de los tratadistas del Siglo de Oro Español», $A E$, n. ${ }^{\circ} 34,1-V I I I-1933$, pp. 352-371; n. ${ }^{\circ} 35,16-V I I I-1933$, pp. 442-461; n. ${ }^{\circ}$ 36, 1-IX1933, pp. 580-590 y n. ${ }^{\circ} 37,16-I X-1933$, pp. 18, y «¿Quiénes pueden ser tiranos en los modernos regímenes democráticos y constitucionales?», AE, n. ${ }^{\circ} 47$, 16-II-1934, pp. 1.105-1.107. 
partidos triunfante en las elecciones. El pueblo cristiano tenía perfecto derecho a cambiar el régimen político si éste no actuaba de acuerdo con los principios de la moral y el beneficio públicos y se convertía en tirano. A ese respecto, Castro Albarrán distinguía entre las actitudes de fuerza contra un soberano legítimo cuya tiranía era prolongada, manifiesta y grave, y a quien en lo posible había que juzgar, y la rebelión contra los actos tiránicos del soberano ilegítimo o usurpador, en la que se podía desplegar el grado máximo de violencia.

En las posibles vías de rebelión contra el poder tiránico, Castro Albarrán se basaba en una interpretación sesgada de la doctrina perfilada por León XIII en la encíclica Libertas (1888) acerca de la libertad para cambiar la organización del Estado cuando a través del gobierno se oprimiese o tiranizarse a la nación. Existían cuatro modos de oponerse al poder ilegítimo de origen o de ejercicio: en primer lugar, la resistencia pasiva, basada en la pura y simple sumisión sin obediencia o acatamiento al régimen. En segundo término, la resistencia activa legal, en la que los disidentes actuaban de acuerdo con los medios permitidos por las leyes vigentes, tales como el obstruccionismo parlamentario o las manifestaciones. Este tipo de actuación, que se asemejaba mucho a la que desplegó el movimiento católico en la campaña en pro de la revisión constitucional, era una lucha constante que tenía las virtudes de acostumbrar a la resistencia ciudadana, ser tolerada por el Gobierno y, por tanto, no estar sujeta a represalias. La tercera modalidad de oposición era la resistencia civil, ilegal pero no armada, basada en actuaciones como la huelga pacífica de funcionarios, el boicot económico o la rebelión fiscal. Castro Albarrán (1933: 328-331) ponía como ejemplo la respuesta de la comunidad católica mexicana a la suspensión del culto en julio de 1926, origen de la lucha cristera y de la persecución religiosa denunciada por Pío XI en su encíclica Acerba Animi de octubre de 1932. La última alternativa era la resistencia armada, basada en el empleo absoluto de la fuerza para repeler una agresión explícita o latente por parte del poder político. Para ello, Castro Albarrán recurría a un teórico de la contrarrevolución monárquica tan conspicuo, pero a la vez tan heterodoxo, como Charles Maurras, quien en su Encuesta sobre la Monarquía afirmaba que la fuerza podía quedar legitimada por razones de necesidad para la instauración de la Monarquía. El magistral de Salamanca pensaba que, llegado el momento, incluso la derecha accidentalista abogaría por la violencia por razones de extrema necesidad, en cuyo caso, según afirmó Gil-Robles, «quisiéramos o no quisiéramos, tendría que surgir una situación de fuerza, que recogiera esa autoridad, que no puede quedar en ningún momento abandonada» (cit. por Castro Albarrán, 1933: 340).

La doctrina del derecho a la rebeldía, formulada para dar de cobertura legal a la actitud insurgente de los católicos o a un golpe de Estado militar en 
ese sentido, se transformó durante la guerra y la posguerra civiles en instrumento de legitimación del Nuevo Estado. Así se entiende la creación por el Ministerio del Interior el 21 de diciembre de 1938 de una comisión encargada de demostrar la ilegitimidad de los poderes actuantes en la República española el 18 de julio9. Vistas todas estas circunstancias, no cabe sino estar de acuerdo con Frances Lannon (1990: 52) cuando comenta que «el antirrepublicanismo implícito y explícito de la Iglesia en los años treinta, que culminó con la entusiasta y celebrada transformación del alzamiento de los generales en una cruzada religiosa, no era menos improvisado y gratuito que el anticlericalismo de la República».

\section{Ramiro de Maeztu y la utopía militarista}

Ramiro de Maeztu fue el más destacado formulador de esta hipótesis militarista en el plano doctrinal, mientras que José Calvo Sotelo trató de aplicarla a la praxis política. En 1923, al tiempo que pedía «tiempo, más tiempo» para el uso del poder dictatorial, el escritor vasco consideraba que éste era compatible en lo fundamental con los principios liberales por su carácter de cirugía puramente coyuntural ${ }^{10}$. Sin embargo, el papel que otorgaba al Ejército como guardián permanente de los valores nacionales y la unidad patria evidenciaba una verdadera formulación ideológica militarista. Ya en su obra La crisis del humanismo, Maeztu definió en sentido schmittiano la teoría militarista como «la que dice que el poder es en sí mismo derecho, y, por lo tanto, subsume el concepto de derecho en el de fuerza» (Maeztu, 1919: 83). Poco después presentaba al espíritu militar como la base en la que se forjaría una nueva sociedad, recordando en sus precisos términos algunas conocidas frases de Spengler y sus primeras veleidades militaristas, que coinciden con las primeras intervenciones corporativas del Ejército en la política española:

«Quizá me engañe, pero se me figura que si el mundo se arregla lo tendrán que arreglar los militares [...] Por eso solía decir a mis amigos, hará diez o doce años, que yo no confiaba la salvación de España sino a la posibilidad de que se les ocurriese salvarla a 49 capitanes. Un grupo de hombres que comiencen por disciplinarse y se adueñen, para empezar, de su propia alma y de su propio cuerpo, que vivan en el mundo, que manden en el mundo, que posean las armas, que sean el ejemplo, que rechacen de su seno a los incapaces de someterse a la misma disciplina, material y moral... No soñemos, Señor,

9. BOE, n. ${ }^{\circ} 175,22-X I I-1938$, pp. 3.079-3.080.

10. «Tiempo, más tiempo», El Sol, 13-X-1923. También en Maeztu, 1957a: 39.

Pasado y Memoria. Revista de Historia Contemporánea, 23, 2021, pp. 160-183 
no soñemos. Pero todos los pueblos son cera para un puñado de hombres que sean a la vez buenos y duros» ${ }^{11}$.

Durante los años veinte, Maeztu consideró la Dictadura primorriverista como un remedio coyuntural que podría impulsar la depuración de la política caciquil y la educación política del pueblo. Ensalzaba las virtudes militares -especialmente el valor, que se desarrollaba con el tónico beneficioso de la guerra- como universales y necesarias, y distinguía la bondad de la lucha y la bondad de la causa, dentro de un tono darwinista en que el espíritu militar era el sustitutivo de la agresividad biológica imprescindible en la lucha por la supervivencia. Aunque Maeztu afirme aborrecer la guerra, ésta implica una tensión, un «cuidado» (Heidegger) y una «angustia» (Kierkegaard) que resultan imprescindibles para la supervivencia de las sociedades. Pero las naciones que daban culto a los valores militares, como lo fue la España de los Austrias, se desgastaron en la guerra y comenzaron su decadencia política, tal como ocurrió al conjunto de Europa tras el conflicto de 1914-1918. De este modo, el culto del valor a través de la guerra encierra un círculo vicioso: el mantenimiento del poder militar depende del sacrificio de las almas generosas y valientes, y esa inmolación de la élite es funesta para la patria, que comienza de este modo su decadencia ${ }^{12}$.

La crisis del sistema liberal llevó a hombres como Maeztu, Yanguas, Pemartín, Calvo Sotelo e incluso Azorín y Eugenio D’Ors a otorgar su apoyo a la Dictadura de Primo de Rivera. José Pemartín, que en sus escritos trató reconciliar las virtudes militaristas del fascismo con los valores católicos y monárquicos del tradicionalismo en una «Monarquía religioso-militar» (Pemartín, 1937: 10-11), llegó a destacar el carácter providencialista del golpe de septiembre de 1923, como respuesta a un deseo divino de salvación frente al desorden que afectaba al país (Pemartín, ¿1929?: 41 ss. y Quiroga, 2006: 51-52). Por su parte, Maeztu vio en Primo de Rivera al «cirujano de hierro» que, al frente de una minoría militar legitimada por sus propias virtudes y su amor a España, podrían liberar a la Monarquía y al país de un sistema político viciado. Contradiciendo a Spengler, no consideraba a la Dictadura española ni al fascismo italiano como muestras de la decadencia europea, sino como un signo del declive del sistema liberalparlamentario ${ }^{13}$. La Dictadura tenía, pues, el gran mérito de haber instalado el orden frente a la subversión fruto de la

11. Ramiro de Maeztu, «El millón de Larache», El Sol, 31-III-1923, cit. por Marrero, 1953: 410.

12. Ramiro de Maeztu, «El espíritu y el poder. El poderío militar», AE, n. ${ }^{\circ} 86$, IV-1936, pp. 71 y 73.

13. El Debate, 8-XI-1923. 
excesiva permisividad del régimen liberal. La actitud frente a los disidentes no dejaba lugar a dudas: «Frente al bolchevismo, la dictadura; frente a la subversión, las bayonetas. Tal es la fórmula del día. Y ello depende de la naturaleza misma del bolchevismo, que no es otra cosa sino la revuelta del subhombre contra la civilización ${ }^{14}$. El órgano promorriverista La Nación aplaudió esta actitud de «cruzada contra el bolchevismo» del escritor alavés, que gustaba mostrar el peligro comunista con los trazos conspiratorios y apocalípticos tan conocidos en otros ámbitos europeos.

Fue en esos años de servicio a la Dictadura cuando Maeztu comenzó a pergeñar una teoría contrarrevolucionaria en la que la simbiosis de doctrina y acción prefiguraba el espíritu de Acción Española. Para este autor, la revolución era un movimiento supranacional de naturaleza conspirativa y elitista que arrancaba del siglo XVIII, y cuyas últimas manifestaciones eran el comunismo soviético y la Segunda República española. Su programa era la subversión de los valores tradicionales mediante una táctica agresiva que provocaba como respuesta un movimiento defensivo y restaurador denominado contrarrevolución, cuyo objetivo era la salvaguardia de los valores hostigados y la rehabilitación de los decaídos. La contrarrevolución era «la reacción de la humanidad civilizada contra la barbarie»; era un movimiento esencialmente espiritual contra los «hombres medio educados», y su propósito era restablecer la unidad moral y material del mundo, rota por la revolución bolchevique. Pero la contrarrevolución no debía ser sólo teoría, sino que tenía que ser llevada a la calle a través de una movilización multifacética:

«Por ser el bolchevismo más acción que idea, la Contrarrevolución ha de ser también un acto, en primer término: el fascio, el Somatén, la dictadura. En Inglaterra adoptó la forma del trabajo voluntario de las clases medias, con que se derrotó la huelga general de hace un año. Pero bajo la protección del fascio, del Somatén, de la dictadura o del servicio social voluntario ha de prepararse la obra espiritual, por la que los pueblos de la tierra han de volver a descubrir en la Religión, en la familia, en el Estado y en la propiedad los fundamentos de la civilización $»^{15}$.

Caída la Dictadura, Maeztu pasó a militar en la Unión Monárquica Nacional, y dedicó gran parte de sus esfuerzos a perfilar definitivamente su idea de la Monarquía Militar mediante una serie de artículos publicados en la revista nacionalista argentina Criterio. Allí expuso la necesidad de una militarización del régimen monárquico español mientras no se forjara una voluntad nacional fuerte que sustituyera a esa solución de fuerza mediante la culminación de

14. Ramiro de Maeztu, «El resentimiento», La Nación, 28-II-1927, p. 1.

15. Ramiro de Maeztu, «La contrarrevolución», La Nación, 4-IV-1927, p. 1. 
su destino imperialista en Hispanoamérica y la eliminación de los peligros revolucionarios foráneos y los movimientos secesionistas regionales. Según Maeztu, en las guerras civiles del siglo XIX habían luchado dos conceptos contrapuestos de Estado: la Monarquía católica tradicional defendida por los carlistas y la Monarquía militar apoyada por los liberales, que a la postre resultó triunfante, pero que después se vio obligada a adoptar caracteres contradictorios con su origen y tradición, al necesitar la constante intervención del Ejército como factor de unidad frente a los «elementos disolventes» como las divisiones regionales, la inoperancia del sistema parlamentario y la amenaza del obrerismo ${ }^{16}$. La misma Restauración fue obra del Ejército, en contra de la opinión de Cánovas. Para Maeztu «el verdadero poder unitario seguía siendo el de la Monarquía militar, mientras que el caciquismo creado por Cánovas era una aristocracia política incoherente a causa de su carácter local, y la oligarquía central no puede funcionar sino por el apoyo o la tolerancia de la Monarquía militar ${ }^{17}$. De ahí las eternas disputas entre el poder civil y el militar, agudizadas por el Desastre, la Guerra del Rif y la Ley de Jurisdicciones. En realidad, la intromisión militarista le parecía la verdadera Constitución de facto, que había garantizado la supervivencia del país en los últimos 180 años. Con todo, este peculiar tipo de régimen, legitimado por el estado de necesidad en que se encontraba España, no era el ideal supremo acariciado por Maeztu, que era la Monarquía tradicional, puesto que la fortaleza política del rey era el principio único y último de autoridad, y un factor fundamental de consenso que hacía innecesaria la intervención salvadora del Ejército. De modo que la Monarquía militar, «hija de las perplejidades que originaron las ideas de la Enciclopedia» era el mal menor, el dique contra la revolución, hasta que las clases dominantes tradicionales, especialmente la Iglesia, lograran recuperar la hegemonía ideológica y se restableciera la unidad de actuación de los tres poderes históricos del país: la corona, el báculo y la espada: «Solamente cuando se haya formado previamente una voluntad nacional unitaria -añadía Maeztu- será posible sustituir la Monarquía Militar. Y entonces será porque la coincidencia de las voluntades individuales forme una voluntad dominadora, que es también una Monarquía, si no militar, al menos militante ${ }^{18}$.

Evidentemente, el punto de llegada deseado por Maeztu era un régimen monárquico idealizado y arcaizante que se sintiera heredero directo del sistema

16. «La necesidad de la Monarquía Militar», Criterio, 21-IV-1931, también en Maeztu, 1957b: 197-202.

17. «La monarquía militar», Criterio, 11-IX-1930, también en Maeztu, 1957b: 196.

18. «La necesidad de la Monarquía Militar», Criterio, 21-IV-1931, también en Maeztu, 1957b: 197-202. 
de gobierno católico y tradicional de los Austrias, tal como lo evocaría en Defensa de la Hispanidad (1934). En el esquema de sus planteamientos idealistas y mesiánicos, consideraba que el regreso a esta utopía contrarrevolucionaria se lograría mediante la acción pedagógica y la convicción intelectual que sobre las grandes masas realizarían los intelectuales afines al sistema (especialmente la Iglesia), en un sentido católico y nacionalista. Sin embargo, la proclamación de la República persuadió a Maeztu de que, además de una reformulación teórica de la Monarquía en sentido antiliberal y autoritario, era necesaria una nueva operación de «cirugía política» por parte de las Fuerzas Armadas en contra de los partidos políticos y la «corrupción democrática». Para ello, otorgó desde abril de 1931 todo su apoyo para una eventual intervención militar de carácter patriótico:

«Los militares intervienen en la política para hacer que se respete el prestigio de su bandera o de su institución, o para evitar que el separatismo, el derrotismo o el pistolerismo destrocen a España; no creo que haya motivo para avergonzarse de su intervención, sino para felicitarse de que existe un Ejército decidido a mantener la unidad nacional $»^{19}$.

El doble objetivo perseguido por Maeztu y el grupo de Acción Española quedaba meridianamente claro: salvaguardia del Ejército como freno a una posible deriva revolucionaria del régimen republicano, y trabajo de los intelectuales en pro del rearme moral y patriótico de la nación hacia un objetivo histórico común, pintado frecuentemente con tintes imperialistas. En último término, el dilema ya no se planteaba entre la Monarquía militar y la católica-tradicional, sino entre la revolución y la contrarrevolución; una prueba de fuerza en la que las Fuerzas Armadas iban a desempeñar un papel fundamental. Por ello, no es de extrañar que uno de los objetivos fundamentales de los responsables de la revista fuera el adoctrinamiento de ese sector del Ejército sentimentalmente monárquico, pero que había mantenido una actitud de inhibición tras el fracaso de la Dictadura y durante el desmoronamiento final del régimen restaurado. Ahora se trataba de movilizarlo con la intención de acabar con la República, y a tal fin se patrocinó en a fines de 1933 la constitución de la sociedad secreta Unión Militar Española (UME). Lleixà (1985: 9) señala que la idea de contrarrevolución preventiva propia de los monárquicos de los años treinta consistía en un juego doble: la ruptura de la legalidad a fin de cercenar un programa de reformas y prevenir su desenlace, y una segunda fase de carácter restaurador propia de las grandes contrarrevoluciones modernas.

19. «La necesidad de la Monarquía Militar», Criterio, 21-IV-1931, también en Maeztu, 1957b: 201. 
Tras el intento revolucionario de octubre de 1934, Maeztu radicalizó aún más sus planteamientos políticos, clamando por una represión ejemplar que dejara al país «pacificado por una o dos generaciones» (Maeztu, 1959: 181183). Desde las páginas de $A B C$, hizo público un llamamiento a la unión de la burguesía conservadora, pero seguía confiando sobre todo en la acción contrarrevolucionaria del Ejército, que acabaría incluso con la amenaza de la revolución:

«Como se me llama militarista desde hace más de veinte años, casi me avergüenza decirlo ahora. No hace falta la ocasión de una guerra extranjera o de una revolución interna. El Ejército nos salva siempre, porque es la unidad en torno a una bandera, porque es la jerarquía, porque es la disciplina, porque es el poder en su manifestación más eminente. En resumen, porque es la civilización ${ }^{20}$.

Siguiendo la doctrina maurrasiana, la contrarrevolución sería, antes que un acto de fuerza, un proceso pedagógico de largo alcance que precisaba de planes constructivos y de la aquiescencia del Estado y de determinadas fuerzas conservadoras contrarrevolucionarias, como el Ejército, la Iglesia, el capitalismo, la aristocracia terrateniente y los profesionales liberales ${ }^{21}$. Como impulsor de este proceso contrarrevolucionario, Maeztu apostaba preferentemente por un Estado autoritario donde el orden público fuera el supremo bien político, plasmado en una dictadura provisional como mal menor que al final desembocase en una Monarquía tradicional, cristiana y corporativa $^{22}$ como régimen de permanencia que podía ser eventualmente salvaguardado por el Ejército, que mantendría siempre su papel de «principal fuerza contrarrevolucionaria» ${ }^{23}$.

En su colección de artículos titulados genéricamente «En vísperas de la tragedia» y aparecidos entre enero y julio de 1936 en La Época con el seudónimo de «Cualquiera», Maeztu afirmó que «es más importante la batalla contra los intelectuales izquierdistas que en sí un golpe militar». Sin embargo, la táctica idónea en este último tramo de la República -y así lo comprendieron políticos avezados como José Calvo Sotelo- enfilaba los derroteros de la acción violenta a través del tradicional recurso al golpe de Estado militar. La actividad contrarrevolucionaria de Maeztu fue puramente teórica y poco eficaz a la hora de planificar una estrategia genuinamente monárquica de tipo restaurador, pero dotó de abundantes recursos ideológicos justificativos del militarismo

20. «El Ejército nos ha salvado», ABC, 26-X-1934, también en Maeztu, 1956: 269.

21. «La revolución», ABC, 1-I-1935, pp. 48-49, también en Maeztu, 1956: 123.

22. «Mal y remedio» y «La Dictadura», $A B C, 30-$ III-1934, p. 3 y 8-VI-1934, p. 3.

23. «La revolución», $A B C$, 1-I-1935, p. 48, también en Maeztu, 1956: 123. 
subyacente durante la crisis de la Restauración y la República, contribuyendo paradójicamente al establecimiento una dictadura militar con voluntad de perdurabilidad.

\section{El appel au soldat de Calvo Sotelo y el proyecto de Bloque Nacional}

La preparación de un golpe de fuerza mediante la propaganda subversiva en las Fuerzas Armadas había sido una de las finalidades planteadas de forma explícita en los estatutos de Renovación Española (RE) nada más surgir como escisión de Acción Popular a inicios de 1933. La táctica de los alfonsinos preveía desencadenar algún acontecimiento imprevisto que acelerara el colapso del régimen republicano y evitase a la vez que la previsible alternativa monárquica restauradora fuera conducida por hombres poco fiables como Gil-Robles o Martínez de Velasco. Pero a medida que, a lo largo de 1935, la derecha católica se acomodaba en el poder, Goicoechea denunciaba que la «táctica» cedista llevaría a una reedición del viejo turnismo liberal que daría pie, como en Francia, a la consolidación de la República laica. La actitud que proponía era similar al retraimiento político ensayado por Cánovas tras el golpe de Pavía: «la situación actual puede llegar a ofrecer, con la de 1874, un marcado paralelismo con la actitud del duque de la Torre: los que hoy defienden la táctica ¿llegarán a obtener un conjunto de condiciones semejantes a las que se lograron en 1874? ¿Llegarán a conseguir una desaparición total de las bases de la Constitución de 1931 y la obtención, por la vía legal y pacífica, de un estado de cosas que equivalga a una monarquía sin monarca?» (cit. por Caballero Audaz, 1935: 83-85). Goicoechea proponía acelerar el deterioro de la situación política para propiciar una solución exclusivamente alfonsina, en la que no tuviese cabida ninguna actitud contemporizadora. Pero ello no se realizaría mediante una poco probable movilización de masas, sino a través del adoctrinamiento de una oficialidad sentimentalmente unida a la Monarquía, y cuyo nacionalismo exaltado le hacía fácilmente manipulable por la extrema derecha.

Este no era necesariamente el mismo plan que defendía Calvo Sotelo, quien se mostraba más interesado en una activa convergencia contrarrevolucionaria de las derechas bajo su mando (Bullón de Mendoza, 2004: 473-486). Calvo Sotelo anunció el 11 de noviembre de 1934 y la creación de un «frente patriótico» que tomase el poder y actuara de dique contra la «amenaza marxista». Este intento de organización de un amplio movimiento contrarrevolucionario de contornos fascistizantes fracasó prácticamente desde sus inicios: Lerroux tildó manifiesto de «vago», y destacó la ausencia de un «caudillo» fascista en 
España ${ }^{24}$. El número de accidentalistas que se pasó al Bloque Nacional fue muy escaso, dadas las esperanzas que aún despertaba la colaboración de la CEDA en el Gobierno y las críticas que Gil-Robles realizó al proyecto calvosotelista. La Comunión Tradicionalista tampoco se mostraba especialmente atraída por su ideario excesivamente estatalista y totalitario, y ello sin contar con su falta de definición monárquica (Blinkhorn, 1979: 268). El propio partido alfonsino aceptó con reticencias el proyecto tras la autorización expresa que el ex-rey dio a Goicoechea y las garantías otorgadas por los «bloquistas» de respetar la independencia de RE (Gil Pecharromán, 1985: I, 543-546).

A lo largo de 1935, los dirigentes alfonsinos acentuaron la difusión de ideas y razonamientos tendentes a la perpetración de un golpe como única salida al impasse contrarrevolucionario abierto tras octubre de 1934. Calvo Sotelo pareció aportar la solución idónea, al divulgar la propuesta de una «dictadura provisional» ejercida por una personalidad monárquica en un régimen nominalmente republicano como nexo entre el golpe militar que se alentaba y la restauración que se deseaba como punto final. La dictadura no era, en su perspectiva, una solución o una forma de gobierno, sino una fórmula de salvación coyuntural al estilo de las de Monk, Serrano o Mac Mahon, o el proceso de restauración emprendido en Grecia desde 1933 (Rodríguez Alonso, 1992: 232).

En una entrevista concedida a Julián Cortés-Cavanillas el 9 de junio, don Alfonso consideraba que «la oportunidad de haber cambiado la paz y aun el régimen fue en octubre, cuando lo de Asturias. Fue el momento de intentar la tarea de salvar a España, en serio, y no se hizo». En cambio, opinaba que la CEDA había claudicado por no haber abandonado el gobierno después de las pretendidas concesiones que los radicales hicieron a las izquierdas sublevadas en octubre anterior (Cortés-Cavanillas, 1973: 326). Sin embargo, a pesar de los incidentes que suscitó durante el matrimonio de su hijo don Juan en octubre de 1935, el antiguo monarca siguió jugando la carta de la restauración «a la griega» hasta el último momento. Ese otoño, don Alfonso seguía barajando la posibilidad de que Gil-Robles asumiese el papel de Tsaldaris, y desde el Ministerio de la Guerra diera el golpe legal que abriese el paso a una dictadura monarquizante, autoritaria y corporativa al estilo de Grecia, Portugal o Hungría, y luego a la restauración borbónica en un plazo breve de tiempo. Pero a la hora de la verdad, los populistas no aprovecharon como sus homólogos griegos el fracaso del movimiento insurreccional de la izquierda para anular a la oposición parlamentaria y establecer una dictadura de facto. Cuando, tras la

24. Informe del embajador francés Jean Herbette, 8-XII-1934, en Archives de Affaires Étrangères, Europe, 1918-1940, Espagne, Politique intérieure, dossier général, leg. 162, pp. 101-103. 
caída de Chapaprieta, Gil-Robles reclamó todo el poder, Alcalá-Zamora abortó la maniobra al precio de disolver el Parlamento. En ese momento trascendental, el líder cedista no reaccionó con la energía que esperaban sus partidarios, y se descalificó ante la extrema derecha como futuro dictador. Aunque la esperanza política del alfonsismo era más un hombre de acción que un doctrinario (Soriano Flores de Lemus, 1975: 16), tampoco resultó factible que Calvo Sotelo hiciera el papel de Condylis ante los mandos más reaccionarios del Ejército o las bases sociales de extrema derecha, que desde 1933 habían optado por Sanjurjo como el hombre fuerte del futuro régimen bonapartista de transición hacia la monarquía.

A medida que el posibilismo cedista agotaba sus posibilidades de reconducir en sentido autoritario la República y RE se enquistaba en actividades propias de un cenáculo minoritario, aumentó la proclividad de los alfonsinos a desarrollar teóricamente alternativas de fuerza. En febrero de 1935, Calvo Sotelo esbozaba los pasos hacia el nuevo régimen: mando único y dictadura con todas las consecuencias; reforma electoral e incluso establecimiento de un sufragio corporativo, que anulase a la izquierda y al centro, y referéndum popular debidamente controlado que abriera el paso a la restauración monárquica (Gil Pecharromán, 1985: I, 418). La transición debería ser progresiva, a través de una tarea de combate contrarrevolucionario que diese prioridad a la actividad intelectual. Pero tampoco se descartaba que la pura presión y la represión militares posibilitaran el cambio de régimen con el apoyo de las derechas monárquicas y accidentalistas tras un triunfo electoral. El Ejército aparecía de nuevo como simple brazo ejecutor para la instauración de un régimen provisional con tintes corporativos y autoritarios, que algunos pensaron identificar como antesala de una Monarquía de tipo tradicional. El factor clave que impedía la realización de este proyecto era, además de la propia debilidad de su organización política, la personalidad del titular de dicha restauración, toda vez que los pasos iniciales para un pacto con los carlistas se habían roto definitivamente con el nombramiento de Fal Conde como secretario general de la Comunión en mayo de 1934, y en el entorno alfonsino se estaba librando una sorda pero despiadada batalla entre la burocracia de RE dirigida por Goicoechea (partidaria de mantener intactos los derechos del exrey Alfonso) y la oficina electoral TYRE y posteriormente el Bloque Nacional controlado por Calvo Sotelo, que apoyaban la tesis instauracionista mediante una cesión de los derechos de ambas ramas dinásticas en la persona del infante don Juan.

Calvo Sotelo también inició una campaña sistemática de adulación al Ejército, al que presentó como víctima del desgobierno republicano. Ya el 6 de noviembre de 1934 había manifestado ante las Cortes sus entusiasmos 
militaristas por contraposición al republicanismo, en su opinión antimilitarista por definición, y exponía por primera vez en público su idea del Ejército como columna vertebral de la nación, símil organicista tomado al parecer de unas declaraciones realizadas por el ministro de la Guerra alemán, general Erich Von Falkenhayn, en 1913:

«Es necesario afirmar la necesidad de que España cuente con un ejército poderoso y devolver la satisfacción moral y la dignidad espiritual a los mandos de ese Ejército; es preciso, en una palabra, que consideremos que el Ejército es el mismo honor de España. El Sr. Azaña decía que el ejército no es más que el brazo de la Patria. Falso, absurdo, sofístico: el ejército se ha visto ahora que es mucho más que el brazo de la Patria; no diré que sea el cerebro, porque no debe serlo, pero es mucho más que el brazo, es la columna vertebral, y si se quiebra, si se dobla, si cruje, se dobla o cruje con él España» ${ }^{25}$.

Esta calificación del Ejército como «columna vertebral» de la nación se contraponía a la tesis azañista y gilrroblista que le asignaba el papel de «brazo ejecutor» de una política gubernamental de carácter nacional (democrática para el primero y antirrevolucionaria en el segundo), y estaba presente también en los escritos de Ortega, cuya conocida teoría de la espiritualidad de la fuerza refirió en ese discurso. La respuesta dada desde la CEDA muestra la inquietud que se sentía ante el riesgo de que el Ejército escapase a su control e iniciara una senda militarista autónoma. Gil-Robles declaró en los locales de AP de Madrid el 22 de diciembre de 1934: «Me alarma cuando en las actuaciones de otros partidos dicen que el Ejército es la espina dorsal de la nación. Me alarma precisamente porque por ser amante del Ejército. Nadie me aventaja en reconocer las glorias del Ejército, sus méritos, sus necesidades. Pero el Ejército no es la espina dorsal, sino el brazo armado de la Patria. La espina dorsal es el mismo pueblo en todas sus clases. La otra afirmación puede significar una adulación, un propósito de utilizar el Ejército con fines políticos para una situación de fuerza» (Gil-Robles, 1968: 635 nota 7).

En este punto resulta interesante constatar las diferencias que se daban en la extrema derecha española respecto al papel político a jugar por el Ejército. Ramiro de Maeztu lo consideraba una de las apoyaturas básicas del régimen tradicional (Monarquía militar) que se habría de instaurar, mientras que Calvo Sotelo, a pesar de sus referencias a la institución armada como «columna vertebral» de la sociedad en tiempo de crisis, le percibía como mero ejecutor de un proceso instauracionista y contrarrevolucionario que habría de desembocar en un Estado fuerte donde la primacía del poder civil estuviese garantizada,

25. DSC, 6-XI-1934, p. 4.553. 
justificando la dictadura sólo como un régimen transitorio. Sin embargo, en ambos casos un militarismo bien dirigido por los monárquicos debería ser la clave de la transformación autoritaria del régimen, hasta desembocar en una monarquía de corte cesarista que ejercería el poder ejecutivo sin trabas de orden constitucional o estamental (Bastos Boubeta, 2006: 80). Por contra, en teoría, Gil-Robles nunca renunció al civilismo, y apoyó al Ejército como aval último de una política gubernamental contrarreformista y contrarrevolucionaria, aunque su fe en la supeditación del poder militar al civil se tambaleó desde la crisis ministerial que dejó a la CEDA fuera del poder en diciembre de 1935. Por fin, los llamamientos de José Antonio Primo de Rivera a los militares se hacían con la intención de obtener de ellos la fuerza que el partido falangista no tenía, aunque siempre bajo su tutela y dirección, pretensión pronto desmentida e incluso efectuada en sentido inverso, toda vez que en el seno del propio Ejército se estaban estableciendo teorías y organizaciones militaristas de carácter perfectamente autónomo. Sin embargo, a la altura de la primavera de 1936 todas las derechas estaban de acuerdo en que un golpe de fuerza militar era el mejor método para acabar de una vez por todas con la República.

\section{Conclusión}

El monarquismo autoritario trató de abordar durante la República cuatro tácticas desestabilizadoras. En el plano doctrinal, desde Acción Española se elaboraron complejas justificaciones de la rebeldía y del militarismo. En el ámbito conspirativo, se recabaron apoyos económicos en el interior y, sobre todo, en el extranjero, especialmente en la Italia fascista. En el terreno político, se trató de suplir la debilidad intrínseca del alfonsismo mediante la concertación de alianzas con otras organizaciones de derechas, como la participación en Acción Nacional, los ensayos de un acuerdo dinástico con los carlistas y el proyecto «bloquista» de Calvo Sotelo. Por último, en el plano insurreccional, se buscó la instrumentalización de organizaciones político-militares que aportaran el necesario potencial ofensivo. De ahí los azarosos intentos de capitalización ideológica del golpe del 10 de agosto de 1932, la búsqueda insistente de un pacto estable con el tradicionalismo, el temporal control del aparato paramilitar de Falange entre agosto de 1933 y noviembre de 1934, la creación frustrada de una juventud y unas milicias no siempre concordantes (las minoritarias Juventudes de RE creadas en abril de 1933 y las no menos raquíticas Guerrillas de España, organizadas a inicios de 1935) y el apoyo económico y la impregnación ideológica de un sector importante de la Unión Militar Española (UME).

Las cuatro tareas fueron culminadas de forma muy desigual: las propuestas teóricas para la subversión no concitaron la adhesión unánime de la Iglesia 
católica y de los grupos políticos antirrepublicanos; la subvención de Mussolini no pasó de discreta hasta el comienzo de la guerra; el alejamiento del carlismo desde mediados de 1934 y la sistemática negativa de la CEDA a apoyar un programa contrarrevolucionario explícito frustraron la tan ansiada creación de un frente antirrepublicano, y tampoco se logró la «satelización» permanente de organizaciones combativas como el Requeté carlista o la Primera Línea falangista.

Los alfonsinos nunca abrigaron esperanzas de que la vuelta a la monarquía se realizara con la aquiescencia de las masas o por un acto insurreccional protagonizado con sus propias fuerzas. Lo suyo eran las tertulias en clubes selectos, las conferencias eruditas en sus centros culturales y las conversaciones conspirativas en las sacristías y los cuartos de banderas. Al estar cultural y materialmente mal preparados para emprender su asalto a la República, echaron mano con diversa fortuna de casi todos los repertorios contrarrevolucionarios de acción a su alcance: incitación al golpe, paramilitarización, frente antirrevolucionario, proselitismo intelectual, participación electoral... Pero la baza subversiva cultivada con mayor mimo, y que prevaleció en última instancia, fue el trabajo sobre el sector antirrepublicano del Ejército con vistas a la realización del tan acariciado «segundo Sagunto». Es cierto que el alfonsismo no llevó la iniciativa en la conspiración y la insurrección de 1936, pero otorgó cobertura teórica a la institucionalización del caudillaje y de un régimen militar duradero, cuya impregnación de los valores del monarquismo autoritario seguía siendo, a pesar de todo, muy limitada. Ello no fue óbice para que, en 1937, José Pemartín proclamase satisfecho que el militarismo campante en la zona rebelde era, en buena parte, resultado de la meticulosa labor de impregnación cultural realizada por los colaboradores de Acción Española: «Como inmediata consecuencia de ese culto al heroísmo profesamos siempre los escritores de Acción Española un militarismo decidido, porque vimos siempre en el Ejército lo que ha mostrado ahora ser: lo más sano, lo más genuinamente español ${ }^{26}$.

La contrarrevolución monárquica contra la Segunda República puede ser calificada de utopía insurreccional en el sentido que Irene Castells dio a su estudio de las conspiraciones y rebeliones liberales de la última etapa del reinado de Fernando VII: una acción subversiva para la que, en principio, no existían condiciones inmediatas de realización, pero cuya minuciosa formulación y tozuda ejecución abrieron -con otros factores ajenos a las mismas- un espacio de oportunidad política que estuvo siempre presente si se daban las condiciones para materializarse.

26. «España como pensamiento», Acción Española, n. ${ }^{\circ}$ 89, marzo 1937, pp. 368-374. 


\section{Bibliografía}

ANSÓN, Luis María (1960). Acción Española. Zaragoza: Círculo.

Aspectos del golpe de Estado. Ensayos leídos en el Circulo de Estudios de la Juventud Monárquica de Bilbao (1933). Bilbao: Jerarquía.

BASTOS BOUBETA, Miguel Anxo (2013). José Calvo Sotelo: ¿tradicionalista o precursor de la política moderna? En Antonio CAÑELLAS (coord.). Conservadores y tradicionalistas en la España del siglo XX (73-94). Gijón: Trea.

BLINKHORN, Martin (1979). Carlismo y contrarrevolución en España, 1931-1939. Barcelona: Crítica.

BULLÓN DE MENDOZA y GÓMEZ DE VALUGERA, Alfonso (2004). José Calvo Sotelo. Barcelona: Ariel.

CABAllero AUDAZ, EL (seud. de José María Carretero Novillo) (1935). Goicoechea y la Restauración: Un hombre. Una doctrina. Una conducta. Madrid: Eds. Caballero Audaz.

CASTELLS OLIVÁN, Irene (1988). La utopía insurreccional del liberalismo: Torrijos y las conspiraciones liberales de la década ominosa. Barcelona: Crítica.

CASTRO ALBARRÁN, Aniceto de (1933). El derecho a la Rebeldía, Madrid: Gráfica Universal.

CASTRO ALBARRÁN, Aniceto de (1941). El derecho al Alzamiento. Salamanca: Talleres Granados.

CORTÉS-CAVANILLAS, Julián (1973). El «bienio santo» de la segunda república. Barcelona: DOPESA.

GARCÍA ESCUDERO, José María (1983). El pensamiento de «El Debate». Un diario católico en la crisis de España, 1911-1936. Madrid: Editorial Católica.

GIL PECHARROMÁN, Julio (1985). Renovación Española. Una alternativa monárquica a la Segunda República. Madrid: Servicio de Reprografía Universidad Complutense, 2 vols.

GIL PECHARROMÁN, Julio (1986). Pensamiento contrarrevolucionario y Revolución Francesa: el caso de Acción Española. Estudios de Historia Social, 36-37, 289-294.

GIL PECHARROMÁN, Julio (1994). Conservadores subversivos. La derecha autoritaria alfonsina (1913-1936). Madrid: EUDEMA.

GIL-ROBLES Y QUIÑONES, José María (1968). No fue posible la paz. Barcelona: Ariel.

GONZÁLEZ CALLEJA, Eduardo (2011). Contrarrevolucionarios. Radicalización violenta de las derechas durante la Segunda República, 1931-1936). Madrid: Alianza.

GONZÁLEZ CUEVAS, Pedro Carlos (1998). Acción Española. Teología política y nacionalismo autoritario en España (1913-1936). Madrid: Tecnos

GONZÁLEZ CUEVAS, Pedro Carlos (2003). Maeztu. Biografía de un nacionalista español. Madrid: Marcial Pons. 
ITURRALDE, Juan de (seud. de Juan José Usabiaga Irazustabarrena) (1955-1965). El catolicismo y la Cruzada de Franco, I. Quiénes y con qué fines prepararon la guerra. VienneBayonaToulouse: Egi Indarra.

LANNON, Frances (1990). Privilegio, persecución y profecía: la Iglesia católica en España, 1875-1975. Madrid: Alianza.

LLEIXÀ, Joaquim (1985). Contrarrevolución monárquica y militarismo en la España de los años treinta. Resumen de tesis. Barcelona: Universitat de Barcelona.

MAEZTU WHITNEY, Ramiro de (1919). La crisis del humanismo. Los principios de autoridad, libertad y función a la luz de la guerra. Barcelona: Minerva.

MAEZTU WHITNEY, Ramiro de (1956). Frente a la República. Madrid: Rialp.

MAEZTU WHITNEY, Ramiro de (1957a). Con el Directorio Militar. Madrid: Editora Nacional.

MAEZTU WHITNEY, Ramiro de (1957b). Liquidación de la Monarquía parlamentaria (vol. XIV de Obras Completas). Madrid: Editora Nacional.

MAEZTU WHITNEY, Ramiro de (1959). El nuevo tradicionalismo y la revolución social. Madrid: Editora Nacional.

MARRERO SUÁREZ, Vicente (1953). Ramiro de Maeztu. Madrid: Rialp.

MARRERO SUÁREZ, Vicente (1962). La guerra española y el "trust» de cerebros, 2. ${ }^{\mathrm{a}}$ ed. Madrid: Punta Europa.

MAURRAS, Charles (1935). Encuesta sobre la Monarquía. Traducción y notas de Fernando Beltrán (seud. de José María Pemán). Madrid: Sociedad General Española de Librería.

MAURRAS, Charles y DUTRAIT-CROZON, Henri (1910). Si le coup de force était possible... París: Nouvelle Librairie Nationale.

MORODO LEONCIO, Raúl (1970). Acción Española: una introducción al pensamiento político de la extrema derecha. En Francisco GRACIA, Javier MUGUERZA y Víctor SÁNCHEZ DE ZAVALA (comps.). Teoría y Sociedad. Homenaje al profesor Aranguren con ocasión de su 60 cumpleaños (361-396). Esplugas de Llobregat: Ariel.

MORODO LEONCIO, Raúl (1980). Acción Española. Orígenes ideológicos del franquismo. Madrid: Júcar.

PEMARTÍN SANJUÁN, José (¿1929?). Los valores históricos de la Dictadura. Madrid: Ed. Arte y Ciencia.

PEMARTÍN SANJUÁN, José (1937). Qué es lo nuevo. Consideraciones sobre el momento español presente. Sevilla: Cultura Española.

QUIROGA FERNÁNDEZ DE SOTO, Alejandro (2006). Los orígenes del nacionalcatolicismo: José Pemartín y la dictadura de Primo de Rivera. Granada: Comares.

RODRÍGUEZ ALONSO, Manuel (1992). El ejemplo de Europa y el enfrentamiento ideológico en la II República a través del periódico La Nación (1934-1936). Hispania Sacra, 44, 89, 217-247.

SÁINZ RODRIGUEZ, Pedro (1980). Testimonio y recuerdos. Barcelona: Planeta. 
SENANTE Y MARTÍNEZ, Manuel (1932). Verdadera doctrina sobre acatamiento y resistencia a los poderes ilegítimos y de hecho: la política tradicionalista [conferencia pronunciada en Valencia el 3 de abril de 1932]. Madrid: Imp. de José Murillo.

SORIANO FLORES DE LEMUS, Julián (1975). Calvo Sotelo ante la Segunda República (La reacción conservadora). Madrid: Editora Nacional.

VEGAS LATAPIÉ, Eugenio (1934). Catolicismo y república: un episodio de la historia de Francia. Madrid: Gráfica Universal.

VEGAS LATAPIÉ, Eugenio (1940). Escritos políticos. Madrid: Cultura Española. 